\title{
MOHAMMED ALI NICHOLAS SA'ID: FROM ENSLAVEMENT TO AMERICAN CIVIL WAR VETERAN
}

\author{
MOHAMMED ALI NICHOLAS SA'ID: DE \\ ESCLAVO A VETERANO DE LA GUERRA CIVIL DE \\ LOS ESTADOS UNIDOS
}

Paul E. Lovejoy

York University

\section{RESUMEN}

Muhammad Ali Sa'id, que tomó el nombre de Nicholas Said después de haber sido bautizado, procedía del estado musulmán de Borno en la década de 1850. Seguirá un periplo que le llevará a través del Sahara hasta La Meca, Istambul y San Petersburgo. Posteriormente viajó como criado por Europa occidental, el Caribe y Norteamérica. Su trayectoria desde que era hijo de un poderoso general y gobernador en Borno hasta su estatus esclavo en el Imperio otomano y, después, como sirviente libre entre la nobleza rusa, le llevó por último a alistarse en el $55^{\circ}$ regimiento de Massachusetts integrado completamente por negros durante la Guerra Civil en los Estados Unidos.

Palabras clave: esclavitud, biografías, Guerra Civil de los Estados Unidos

\begin{abstract}
Muhammad Ali Sa'id, who was renamed Nicholas Said upon his baptism, came from the Muslim state of Borno in the 1850s, following an odyssey that took him across the Sahara, to Mecca, Istanbul and St. Petersburg. He susbsequently traveled as a valet through western Europe to the Caribbean and North America. His trajectory from the son of a powerful general and governor in Borno to his enslaved status in the Ottoman Empire and then to a position as a freed servant to Russian nobility ultimately led to his enlistment in the all-black 55th Massachusetts Regiment during the Civil War in the United States.
\end{abstract}

Keywords: slavery, biography, American Civil War 
Mohammaed Ali Sa'id, known in Europe and North America as Nicholas Said, had a most astonishing career as a soldier in the American Civil War and, thereafter, was an unsung voice of Reconstruction in the southern United States.' He was raised a devote Muslim and indeed as a slave had been on the pilgrimage to Mecca, although because of his status he was not able to claim that he had completed the pilgrimage. His promotion to sergeant in the Union Army in itself was unusual, and being born in Africa, the son of a distinguished general, makes his life even more so. His odyssey was unique in the history of Africans in North America. Enslaved by Tuareg nomads, he was taken to the Ottoman Empire and Tsarist Russia rather than via the Middle Passage across the Atlantic to the Americas. Unlike those whose liberty he fought to secure in the United States, Sa'id crossed the Atlantic as a free man who had been emancipated in Russia less than a decade after he had been enslaved near the shores of Lake Chad, south of the Sahara. His enslavement across the Sahara, rather than the Atlantic, involved a very different experience of Middle Passage. Sa'id went to Tripoli, Cairo, and the Muslim Holy Lands of Mecca and Medina, and then to Istanbul. From there, he went to Imperial Russia as a freed servant to a Russian diplomat, and subsequently traveled extensively in western Europe. He then journeyed to North America and the Caribbean as the valet in the employ of a Dutch citizen before he enlisted in the Union Army. As Sa'id observed, "Truth told, I had seen so many wonderful and unexpected sights

1 I wish to thank Abubakar Babajo Sani, Umaru Musa Yar'adua University, Katsina, and Mohammed Bashir Salau, University of Mississippi for their comments on this paper. Guylaine Petrin, Alicia Schrikker, Hakan Erdem, Ismail Hakki Kadi, Dean Calbreath, and Dorothy Granberry have provided invaluable details on specific aspects of Sa'id's life. The paper has been done under the auspices of the Canada Research Chair in African Diaspora History with support from the Social Sciences and Humanities Research Council of Canada. 
within the few previous years, that I think my organ of marvellousness had gone to sleep from sheer surfeit and exhaustion, and I took everything as a matter of course". 2

Sa'id was born in about 1836 and enslaved when he was in his mid teens, apparently in 1851. Against his mother's instructions, he joined a party of other young men on a hunting expedition between Kukawa and Lake Chad, near Lari, where he and his friends were ambushed by marauding Tuareg nomads. The Tuareg raiders sold him to Abd-el-Kader, a merchant who took him first to Katsina in the Sokoto Caliphate and then via caravan across the Sahara. They passed the desert oasis of Bilma, an important source of salt, and then continued to Murzuq, where he was sold to a Turkish officer, Aga Abdy, who was Albanian. Aga Abdy took Sa'id to Tripoli and presented him to his father, Hadii Daoud, who "owned an extensive tobacco store in the Turkish bazaar". In Tripoli, Sa'id met his comrades who had also been kidnapped, and while they were all ransomed and sent home to Borno, Sa'id remained in slavery. Daoud apparently realized that he had a particularly gifted young man and had other ideas in mind than the recovery of his investment; the price of ransoming was usually twice the cost of a slave. Instead, Daoud took Sa'id on pilgrimage, traveling via Benghazi, Alexandria, and Cairo (staying at the port of Boulak on the Nile), to Khartoum, where they stayed five weeks. They continued to Gondar, Massawa, Zeila, and Jedda, remaining in Mecca four months and at Medina at least six weeks. On leaving the Hijaz, they went to Muscat, where they stayed another month, before returning to Tripoli via Suez. Back at Tripoli Daoud learned that the market had burned down, destroying his tobacco shop and all his personal wealth. Daoud was forced to sell Sa'id and therefore sent him to Izmir (Smyrna). After three weeks, Mehmed Fuad Pacha (1814-1869), who lived in "Kandji Koolook," probably Kalyoncu Kulluğu in the Tarlabaşi district in current Beyoğlu. ${ }^{3}$ At the time he was the Foreign Minister of the Ottoman state and would soon become the chairman of the Tanzimat council that was implementing reforms in the Ottoman government. At this point, Sa'id was a "tchiboudji" (çubukçu, that is, someone who prepared and cleaned pipes for smoking cigarettes, including water pipes) and was taken to Istanbul. After nine months, Sa'id was sold or more likely given to Fuad Pacha's brother-in-law, Mustafa Rechid Pacha

2 SA'ID, M.A. (1873), The Autobiography of Nicholas Said; A Native of Bornou, Eastern Soudan, Central Africa, Shotwell \& Co., Memphis, pp. $78-79$ (http://docsouth.unc.edu/neh/ said/said.html).

3 I wish to thank Ismail Hakki Kadi for this identification. 
(1800-1858), who had been the architect of the Edict of Gülhane (1839) which launched the Tanzimat reforms and who was involved in peace negotiations to end the Crimean War in 1856.

Sa'id was destined for even further adventures. Rechid Pacha apparently gave Sa'id to Prince Alexander Sergeyevich Menshikov (1787-1869), the Russian ambassador to the Ottoman court, who was greatly impressed with the young man. ${ }^{4}$ Sa'id was taken to Odessa, where he was instructed in Russian, which he mastered in a matter of a few weeks. When Menshikov withdrew from Istanbul in 1853 during the tensions that led to the Crimean War in 1853, Sa'id was with him, traveling via ship to Athens and the Aegean Sea before taking the train to Vienna, Krakow, and Warsaw to St. Petersburg. Sa'id stayed with Menshikov in his mansion on Nevsky Prospect, the main avenue in St. Petersburg, and also in Boshoy Morskoy in the center of the city. When Menshikov was posted to the Crimea as commander-in-chief of the Russian army in October 1853, Sa'id moved on, now into the household of Prince Nikolai Petrovitch Troubetzkoy (1828-1900), who with Nikolai Rubenstein, brother of Anton Rubenstein, had founded the Moscow Conservatory in 1866. Sa'id accompanied Troubetzkoy to Moscow and his estate at Akhtyrka, where Anton Rubenstein, Pyotr llyich Tchaikovsky, and other composers gathered. Troubetzkoy insisted that Sa'id learn French and that he convert to the Orthodox Church. Sa'id was thereby baptized in Riga, a Livonian city, later capital of Latvia, as Nicholas, which took place on the 12th of November, 1855 (i.e., 31 October 1855). Sa'id then accompanied Trobetzkoy on a tour of western Europe, visiting among other places, Baden-Baden, Dormstadt, Frankfort-am-Main, Aix-la-Chapelle, Cologne, Belgium, Salzburg, and Munich. At Rome in 1856, Sa'id visited the Vatican on numerous occasions, until May 25, 1857, whereupon Trobetzkoy travelled to Marseilles, Paris, and London. In London, they resided just off Hanover Square near Oxford Circus, and as elsewhere, Sa'id had the opportunity as Trobetzkoy's servant to meet the most important dignitaries in England, including Queen Victoria. In 1858 and 1859, Sa'id went with Troubetzkoy to Italy, Germany, France and back to England, continuing his adventures. Of Paris, Sa'id observed "I believe there is more wealth and more wretchedness, more learning and more vice, more gayety and less

4 SA'ID (Autobiography, 124) says that Mentshikov "offered a large price for me, but, under the then existing Turkish law, a Mohammed slave could not be sold out of the empire; so the matter was clandestinely compromised by the Pacha presenting me to the Prince", which meant that this was a giff. As the renowned reformer of the Ottoman government, Rechid Pasha would not have violated religious law and custom that forbade sale of slaves to non-Muslims and foreigners. 
virtue in Paris than in any other city in the world." 5 Perhaps because of this over indulgence, Sa'id informed Troubetzkoy in late 1859 that he wanted to return to Borno, at least for a year, and therefore left his employment.

His return to Borno was delayed, however, when he was offered a position as the valet to Isaac Jacobus Rochussen (1829-1907), once a minor official in Dutch Suriname and somewhat of a scoundrel. ${ }^{6}$ Rochussen had recently married Katherine Anne Drake in Wells, Sussex, and the couple intended a tour of the Caribbean and North America. They arrived in Portland, Maine in December 1859, traveled to Boston and then New York, where an incident occurred that Sa'id does not recount in his autobiography. On January 8, 1860 the Rochussens went to the Church of the Puritans in Union Square to hear the Rev. George B. Cheever, a noted abolitionist, preach a sermon "God against Slavery," but made the mistake of sitting in the wrong pews. Blacks were supposed to sit in a specially designated part of the church, but Sa'id sat in the row behind the Rochussens and was told to move. Incensed, the Rochussens left the church and wrote a letter that was published in the London Anti-Slavery Reporter (February 1, 1860) and republished in the New York Times (February 24), with some controversial discussion that followed.

From New York, the Rochussens, along with Sa'id, went to Nassau in the Bahamas, Cap Haitien and Port-au-Prince in Haiti, and then on to Suriname, returning to New York via Jamaica and Nassau. From New York, they went to Saratoga Springs, Niagara Falls, remaining two weeks, and on to Hamilton, Toronto, Kingston, Montreal, Ottawa, and across the Ottawa River to Aylmer, where they booked in at the British Hotel. While there, Rochussen was suddenly called to Montreal for unexplained reasons. His wife initially remained behind but soon joined her husband, and unknown to Sa'id the couple moved to Vermont, abandoning their luggage and leaving Sa'id

5 SA'ID, Autobiography, p. 182

6 I wish to thank Alicia F. Schrikker for information on Rochussen's Dutch background; see Ambtenaren ter beschikking van den gouverneur, the 1860 almanac for the Dutch West Indies, (http://www.dbnl.org/tekst/_alm009186001_01/_alm009186001_01_0022.php). The title "Landdrost" was probably associated with this position. Also see the Rochussen genealogical website (http://www.inevanmeer.nl/rochussen/rochussen_isaac_jacobus_379.html). 
with a considerable hotel bill which they had not paid. ${ }^{7}$ When the Rochussens failed to return to Alymer, Sa'id had to leave the hotel, minus his own belongings, including all his Turkish costumes. He found work on a steamer that went from Ogdensburg on the St. Lawrence River to Detroit, where he was lucky to meet the Rev. George Duffield (1794-1868) of the Protestant (Presbyterian) Church, whom he had met on board ship in the Aegean when Sa'id had left Istanbul for St. Petersburg, and who now helped him get a position teaching French, of all languages, to the African American community in Detroit. From Detroit, he visited Toledo and from there went to Bellefontaine for some unknown reason and then to Sandusky City, on the shores of Lake Erie and an important departure point for African Americans attempting to reach Canada on the Underground Railroad via the lake crossing.

In early 1863, responding to a recruitment campaign, Sa'id enlisted in

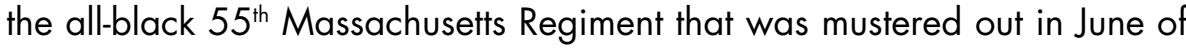
that year. The $55^{\text {th }}$ fought mostly in South Carolina, first at James Island in May and July 1864 and at Honey Hill on November $30^{\text {th }}$. The $55^{\text {th }}$ was involved again at James Island and at Briggen Creek in February 1865 and at Saint Stephens on March $1^{\text {st }}$ before occupying Charleston. After the Civil War, Sa'id taught school for two years in Charleston and was appointed to the Board of Registration for the District of Berkeley, north of Charleston, in 1867. Thereafter, he moved to Thomasville, Georgia, where he also taught school and where he claims to have begun to write his autobiography, although there is evidence that he had already started that task, as documented in the October issue of Atlantic Monthly. ${ }^{8}$ By this time he was giving public lectures in various cities and towns in Florida, Georgia, South Carolina and Alabama, while he also continued to teach school. After he left Thomasville, he moved to Alabama, first teaching in Abbeville

7 Unbeknownst to Sa'id, Rochussen settled in Franklin County, Vermont and became a lawyer. Later he moved to Minnesota, then Kansas and finally California, while Mrs. Rochussen moved to Sutton, Quebec, without her husband sometime before 1880. Thanks also to Guylaine Petrin for pursuing Rochussen in North America; see especially his admission to the bar in Vermont in 1865; as cited in ALDRICH, L.C. (ed.) (1881), History of Franklin and Grand Isle Counties Vermont. D. Mason and Co., Syracuse, p. 232; and his naturalization in Vermont in 1868, as recorded in "United States, New England Petitions for Naturalization Index, 1791-1906", NARA microfilm publication M1299 (Washington DC: National Archives and Records Administration, n.d.), roll 103; FHL microfilm 1,429,773). Also see ANDREAS, A.T. (1883), History of the State of Kansas (Supplementary History and Description of its Counties Cities Towns and Villages). A.T. Andreas, Chicago, p. 1130.

8 SA'ID, N. (1867), "A Native of Bornou", Atlantic Monthly, vol. 20, pp. 485-495. 
and finally reaching St. Stephens, in Washington County, in March 1872, where he "conceived the idea of settling myself for life." In Alabama, he married Mournin Jackson in Choctaw County on September 28, 1874, but apparently he also married Rachael [Rebecca??] Thornton of Clarke County, across the river from St. Stephens, also in 1874. He subsequently moved to Brownsville, Tennessee, where he taught school, boarding with Cincinnati Jordan, and where he allegedly died in 1882, although other information suggests that he moved on and was still alive until 1898 .

What we know of this fascinating man is derived not only from his own accounts but also from Civil War records, newspaper stories, other materials, and the verifiable history of his African origins. Based on his own testimony, Sa'id was born in Kukawa, the capital of Borno, in about 1836, but perhaps 1834, into a prominent family. At the time, the Muslim country of Borno had withstood the powerful forces of jihād that had transformed the political landscape of the vast region known in Arabic as the Sudan, the land of the blacks. As Sa'id recounts in his autobiography, first published in Atlantic Monthly in 1867 and then more fully in The Autobiography of Nicholas Said; A Native of Bornou, Eastern Soudan, Central Africa by Shotwell \& Co. in Memphis in 1873, he was associated with the elites of countries from sub-Saharan Africa to the Ottoman Empire, Russia, Western Europe and North America, but despite his fascinating connections he virtually slipped into obscurity after the Civil War and has been largely ignored. He had often discussed his interesting life while he was a soldier in the $55^{\text {th }}$ Regiment, even committing his account to writing. While that manuscript has not been recovered, part of it appears to have formed the Atlantic Monthly article. A photograph of him in a Union uniform in the Massachusetts Historical Society reveals a handsome man, ${ }^{9}$ whom the Savanna Daily Advertiser referred to as a "wandering African celebrity" in 1871, although in a derogatory fashion. The Macon Weekly Telegraph was even more unflattering, calling him "a semi civilized part of the African persuasion named Nicholas Said, who has been traveling over Georgia the past year or two..., devoting his valuable time at present to swindling the newspapers". One of the newspapers that was more impressed was the Cincinnati Daily Enquirer, which considered him "a rather notable African" in its April 17, 1870 edition, praising him for "delivering a course of lectures, or rather a series of addresses to the colored people", which is confirmed by the Macon Weekly Telegraph that this "rather notable darkey" was on "tour

9 SAIB, Nochlas. Carte de Visite by Marshall \& Company, ca. 1863. Wolcott Civil War Album, 55th Massachusetts Infantry Regiment, MHS image number 242. 
through the Southern States" for the purpose of telling his story. The Weekly Telegraph noted on March 8, 1870 that "he has been well educated, and speaks and writes fluently the English, French and Italian languages, while he also delights in his mother tongue", i.e., Kanuri. As Sa'id admitted, "I have possessed, all my life an extraordinary aptitude for the acquirement of languages". ${ }^{10}$ His autobiographical accounts confirm this amazing gift for language. He was barely 37 years old when he published his autobiography in 1873 and probably 46 when he died.

His life story was indeed unusual. From the time he was a boy, he was in the palaces of the ruling oligarchies across the Islamic world and Europe. In Borno before he was kidnapped, he was privy to the momentous events of the jihäd that established the Sokoto Caliphate and led to the reform of the Borno state. His account of the dynamic leadership of Muhammad al-Kanemi, who successfully overcame the massive invasion of the Sokoto jihād forces that almost destroyed Borno in 1810 provides a view of history that is well informed and insightful. In 1810, the beleaguered Sayfawa dynasty was forced to evacuate the capital at Birni Ngazargamu on the Komodugu Yo River, the western tributary of Lake Chad. Not only was the capital destroyed, but the densely populated region around the capital had to be evacuated, with many of its inhabitants reduced to slavery, removed to the centers of the Sokoto Caliphate and even sold south into Yoruba country and the Atlantic slave trade. A new capital was built at Kukawa, to the east, where Sa'id was born.

Because of the Sokoto jihād, Borno was reduced from a position of dominance in the vast basin of Lake Chad under the ancient dynasty of the Sayfawa to a third of its former territory. Sa'id's description of the jihād and the emergence of Sokoto as an Islamic empire that stretched from modern Burkino Fasso across southern Niger and most of northern Nigeria into northern Cameroon is one of the few accounts of the jihād that provide critical commentary on the emergence of Sokoto as the largest state in Africa in the nineteenth century. Moreover, Sa'id's testimony provides details that only an informed witness and someone who had access to official circles in the Borno government could authenticate. The details of his remarkable life might otherwise seem fanciful, and indeed his most authoritative biographer has raised questions of his veracity, but on close examination Sa'id's account establishes that it is clearly authentic. ${ }^{11}$

10 SA'ID, Autobiography, 73-74.

11 AUSTIN, A.D. (2008), "Mohammed Ali Ben Said: Travels on Five Continents", Contributions in Black Studies, vol. 12, pp. 129-158. Austin also discusses Sa'id in AUSTIN. A.D. (1997), Af- 
Sa'id's father was none other than Barka Gana, governor of several provinces in the region of the Ubangi and Shari Rivers that flowed into Lake Chad at the time of his death in 1846. Barka Gana was a slave general in the Borno army, with the title, "Kaigama of the Right".

Slave officials were features of Muslim countries throughout the lands of Islam from Morocco to India and indeed in sub-Saharan Africa. Such royal slaves were prominent in the various emirate governments of the Sokoto Caliphate, as well as Borno. Barka Gana had been brought up in al-Kanemi's household since the age of seven, according to British diplomat, Dixon Denham, who knew Barka Gana in 1822-1824.12 Although Denham thought that Barka Gana was "a bigoted Musselman", he confirmed Barka Gana's role in consolidating al-Kanemi as de facto ruler of Borno. The Sayfawa dynasty attempted to regain control of Borno in 1846, which Sa'id describes, when Mai Ibrahim sought the military assistance of Wadai from east of Lake Chad against al-Kanemi's son, Shehu 'Umar. Wadai was repulsed but only after destroying much of Kukawa, which had to be rebuilt. Mai Ibrahim was then executed, marking the end of the Safawa dynasty. Sa'id's account thereby helps in the reconstruction of crucial events in the history of the Sokoto jihād and its impact on Borno. Sa'id's father also lost his life during the Wadai invasion, which Sa'id noted had occurred when he was about "twelve or thirteen years old", which suggests that he was born in 1833 or 1834 , not 1836 as he later claimed.

rican Muslims in Antebellum America: Transatlantic Stories and Spiritual Struggles. Routledge, New York. Also see DIOUF, S.A. (1998), Servants of Allah: African Muslims Enslaved in the Americas. New York UP, New York; and GOMEZ, M. (2005), Black Crescent: The Experience and Legacy of African Muslims in the Americas. Cambridge UP, Cambridge, although neither Diouf or Gomez draw on material beyond the Atlantic Monthly article. Safet Dabivic uses the 1873 autobiography but otherwise adds little to the documentation of Sa'id's life; see also DABIVIC, S. (2012), "Out of Place: The Travels of Nicholas Said". Criticism, vol. 54:1, pp. 59-83. Also see HORN, P.E. (2012), "Coercions, Conversions, Subversions: The Nineteenth-Century Slave Narratives of Omar ibn Said, Mahommah Gardo Baquaqua, and Nicholas Said". Auto/ Biography Studies, vol. 27:1, pp. 45-66, although it should be noted that Horn makes many mistakes and adds no new information on Sa'id's life.

12 For Denham's account of Barka Gana, see DENHAM, D., CLAPPERTON H. and OUDNEY, W. (1828), Narrative of Travels and Discoveries in Northern and Central Africa in the Years 1822, 1823, and 1824. John Murray, London, 3rd ed., vol. I, pp. 210-211, 243, 260, 267. 287, 292, 299-306, 314-329, 375, 417, 446, and 454. Also see BRENNER, L. (1973), The Shehus of Kukawa. A History of the Al-Kanemi Dynasty of Bornu. Clarendon Press, Oxford, pp. 45-46, 60, 65, and 100; and LOCKHART, J.R.B. (1996), Clapperton in Borno. Rüdiger Köppe Verlag, Köln, pp. 133, 208, and 210-211. 
Both the Atlantic Monthly article and his autobiography are well written, without evidence of substantial editing by another person. Sa'id based his article in the Atlantic Monthly on "portions of his history" which he had recited "from time to time" and was "condensed" from a much longer manuscript". He began the article with the disclaimer,

"Reader, you must excuse me for the mistakes which this article will contain, as you will bear in mind that this language in which I am now trying to write is not my mother tongue; on the other hand, I never had a teacher, nor ever was at school for the purpose of acquiring the English [language]. The only way I learned what little of the language I know was through French books".

Despite his modesty, Sa'id had mastered English to a considerable degree, which was reflected in his speaking tours and his teaching. Nonetheless, he asserted the limitations on his command of English in his autobiography, apologizing for "an indiscriminate use of the present and past tenses in my narrative", and "the difficulties I have experienced in distinguishing English idioms and modes of expression from those of the other languages with which I am acquainted, and some of which are more familiar to me than the English itself". He noted that

"Pure English can hardly be expected from one who has to choose his words and phrases from a mass of Kanouri (my vernacular), Mandra [Mandara], Arabic, Turkish, Russian, German, Italian and French, and all of them encumbered with the provincialisms necessarily concomitant upon each. In the spelling of proper names, too, I sometimes infringe the rule".

Sa'id probably spoke some Hausa and seems to have learned Armenian as well.

How Sa'id came to the attention of Atlantic Monthly in 1867 is uncertain. His editor is not identified, although the editor had known Sa'id when

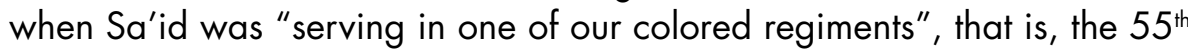
Massachusetts. Very likely, therefore, the unnamed editor was Norwood Penrose Hallowell, the commanding officer of Sa'id's regiment. Sa'id stood out because of the "tattooing on his face" that were probably the characteristic Kanuri facial scarification that was used in Borno. He was described as being "of medium height, somewhat slenderly [sic] built, with pleasing fea- 
tures, not of the extreme negro type [sic], complexion perfectly black, and quiet and unassuming address". A photograph has survived that pictures Sa'id in a Union uniform while serving in the $55^{\text {th }}$.

Interesting questions arise from Sa'id's account. He mentions meeting British diplomat and German scholar Heinrich Barth in Kukawa, most certainly in 1851. Barth visited Kukawa twice during his travels in West Africa between 1849 and 1856. His massive report on his mission as official British diplomat comprises 2,266 pages in three volumes, including 204 illustrations and detailed maps of his itinerary. Barth also published three separate volumes of vocabularies of eight African languages, as well as numerous reports in German and British geographical journals. The question arises as to how Sa'id knew that the man he met in Kukawa as a teenager was this distinguished scholar but probably because he met Barth in London, perhaps at the Royal Geographical Society at the time of the publications of Barth's travels, whether or not Sa'id ever read Barth's accounts. ${ }^{13}$ Barth's major publication appeared in London and New York in 1857, and hence it is most likely that Sa'id somehow met Barth in London between 1857 and 1859, but there is no evidence yet that he did.

Although Sa'id had completed the pilgrimage to Mecca, he could not claim the distinction of being an al-haij because of his slave status, and in Russia he was baptized into the Greek Orthodox Church. Nonetheless, in his autobiography in 1873, he claimed that he was affiliated with the Swedenborgians, a fringe Christian sect of Swedish origin that believed that the "Lord's Human is Divine [and] that love to the Lord and charity toward the neighbor constitute the church, and not faith separate from love and charity". It appears that his introduction to Swedenborgianism took place in Charleston in 1865. The emphasis of the Swendenborgian creed on the supreme Lord and the importance of charity seem to be more akin to his upbringing as a Muslim than the Orthodox Christian faith to which he had nominally converted.

Finally, Sa'id clearly falsified the dates of his travels in North America and the Caribbean, apparently in an attempt to suppress the Civil War years. We know he arrived in Portland, Maine in late 1859 because he was in New York in January 1860, as revealed by the incident at the Union Square church. We know from the records of the 55th Massachusetts Regiment of

13 BARTH, H. (1859), Travels and Discoveries in North and Central Africa. Harper and Brothers, New York, 3 vols; and BARTH, H. (1862), Sammlung und bearbeitung central-afrikanischer vokabularien. Collection of Vocabularies of Central-African Languages. Justas Perthes, Gotha, 3 vols. 
his stint in the Civil War, which is further documented by his photograph in a Union uniform. We also know from the introduction to the Atlantic Monthly article that he had fought in the Civil War and had frequently narrated his life history. It is likely, therefore, that he suppressed these details because of his experience in the South after the Civil War, first in South Carolina, then Georgia and Alabama. He noted the activities of the Ku Klux Klan and expressed admiration for Benjamin Franklin Randolph, whom he met in Charleston and who subsequently was elected to the South Carolina State Senate, but whom the Klan murdered in the fall of 1868. Sa'id's speaking engagements were noticed and he was attacked in various newspapers in South Carolina and Georgia, despite his favorable comments about some former Confederate officers, including the future governor of Alabama, Col. William C. Oates. His celebrity status was noticed in the Cincinnati Daily Enquirer on April 17, 1870 as "a rather notable African" with extensive details of his life. When Sa'id opened a bank account in Tallahassee, Florida in 1871, he was described as the "wonderful" Nicholas Said. However, the Macon Weekly Telegraph defamed him on May 23, 1871 as "a semi civilized party of the African persuasion...devoting his time at present to swindling the newspapers" and the Savannah Daily Advertiser of July 1, 1871 dismissed him as "the wandering African celebrity" who was in reality a "humbug" who "should quit drinking whiskey by the wholesale".

Nonetheless, Sa'id's enlistment in an all black regiment stands out as a brave statement of solidarity with those who were fighting to end slavery. His appointment in South Carolina to register voters, his commitment to teaching, and his association with African Americans who were involved in the Reconstruction era also stand out. ${ }^{14}$ Sa'id clearly had developed a strong sense of political consciousness. He denounced "that plague of humanity, prejudice of color, or rather of condition. Prejudice hardens the heart, beclouds the judgment, prejudice exposes and magnifies the faults, and overlooks and covers up the virtues of a fellow creature".$^{15}$

"My motive in this publication I believe to be good: a desire to show the world the possibilities that may be accomplished by the African, and the hope that my humble example may stimulate some at least of my people to systematic efforts in the direction of mental culture and improvement".

14 "Headquarters, Second Military District", Charleston Courier, July 31 st, 1867, 4.

15 SA'ID, Autobiograhy, pp. 223-224. 
His contributions as a teacher demonstrate his determination to help people of African descent overcome the legacy of slavery. Nonetheless, his autobiography remained virtually unknown until a Harvard divinity student, Precious Rasheeda Muhammad, stumbled across the text in 2000.16 If Sa'id's book had been known previously, it would surely have been cited in scholarly publications, which it has not been until recently.

Sa'id's life story connects two parts of the broader Atlantic world, the Islamic interior of West Africa, and the United States specifically, during the period that has been referred to as the era of the "second slavery". Originally developed by Dale Tomich and his associates, "second slavery" emphasizes the intensification of slavery as an institution after the spread of the abolition movement, first with reference to the trans-Atlantic slave trade, particularly after 1807 when Britain and the United States withdrew from the trade, and then with the movement to emancipate the enslaved population in the Americas, first achieved in St. Domingue and the emergence of Haiti as an independent state in $1804 .{ }^{17}$ Tomich's analysis focused especially on Cuba, Brazil and the southern United States, while subsequent study has drawn attention to the great expansion in slavery in the Islamic states of

16 HENRY, T.T. (2002), "Student Uncovers Rare Ex-Slave's Narrative", http://www.africana. com/DailyArticles/index_20001003.htm. Also see MUHAMMAD, P.R. (ed.) (2000), The Autobiography of Nicholas Said: A Native of Bornou, Eastern Soudan, Central Africa, Journal of Islam in America Press.

17 TOMICH, D. (2004), Through the Prism of Slavery: Labor, Capital and World Economy. Bowman \& Littlefield, Lantham; KAYE, A.E. (2009), "The Second Slavery: Modernity in the Nineteenth-Century South and the Atlantic World". Journal of Southern History, vol. 75:3, p. 627. Also see TOMICH, D. (1988), "The 'Second Slavery': Bonded Labor and the Transformations of the Nineteenth-Century World Economy", in RAMÍREZ F.O. (ed.) (1988), Rethinking the Nineteenth Century: Contradictions and Movement. Praeger, New York, pp. 103-117; TOMICH D. and ZEUSKE, M. (eds.) (2008), The Second Slavery: Mass Slavery, World-Economy, and Comparative Microhistories, Part II, special issue of Review: A Journal of the Fernand Braudel Center, vol. 31; and ZEUSKE, M. (2012), "Historiography and Research Problems of Slavery and the Slave Trade in a Global-Historical Perspective". International Review of Social History, vol. 57:1, pp. 87-111. 
West Africa. ${ }^{18}$ Muhammad Ali Sa'id came from Borno, which under Shehu al-Kanemi and indeed his own father, witnessed the consolidation of a slave economy in Borno that was parallel to the equally profound developments in neighboring Sokoto Caliphate. After he became Nicholas Said in Riga, Latvia, he subsequently traveled through the Caribbean before settling in the United States and enrolling in the 55th Massachusetts Regiment and fighting in the Civil War that ended the "second slavery" there. His life's odyssey therefore connected two widely separated parts of the world that were parallel in terms of the importance of slavery. His career after the Civil War contributed to the efforts at Reconstruction, albeit without lasting impact because of the emergence of the Jim Crow era.

18 LOVEJOY, P.E. (2016), "Jihad and the Era of Second Slavery". Journal of Global Slavery, vol. 1, pp. 28-43; and developed more fully in LOVEJOY, P. (2016), Jihad in West Africa during the Age of Revolutions. Ohio UP, Athens. 